\title{
Diversity as a Competitive Advantage? A Case Study of Immigrant Labour in Swedish Agriculture
}

\author{
Henrik Barth \\ Halmstad University
}

This paper investigates cultural diversity as means to business sustainability and competitive advantage for entrepreneurs in the agricultural sector. 80 agricultural entrepreneurs have been addressed in this study, which include face-to-face meetings between entrepreneurs and candidates for employment.

While supportive of the idea of cultural diversity as a beneficial element of business sustainability, most farmers stated they lacked both the time and the resources to manage the issues associated with immigrant workers. However, lack of organisational changes and managerial skills can also be a potential barrier for integration when the farm address growth and employment ambitions.

\section{INTRODUCTION}

Migration and the integration of immigrants are important issues for many countries. For example, more than a million migrants and refugees entered the European Union (EU) in 2015 (Eurostat, 2017). A few countries took a greater number of asylum refugees than others. Of the EU nations, Sweden has processed the second highest number of refugee applications in proportion to its population (only Germany has recorded more applications). In 2015, Sweden approved 1667 refugee applications per 100.000 inhabitants. The EU on the whole approved 260 refugee applications per 100.000 inhabitants in the same year (Eurostat, 2017).

This influx of immigrants in Sweden has posed significant challenges for Swedish society. While many of the immigrants who entered Sweden in 2015 (and later) are now obtaining residence permits, finding work for them has been more problematic. The greatest challenge is to train, educate, and prepare them to enter the Swedish workforce.

Statistics Sweden (2017) provides relevant data on this problem. Of the foreign-born people in Sweden between the ages of 25 and 64 years with post-secondary education, $75 \%$ were gainfully employed in 2015. By contrast, of the native-born people in Sweden, of a comparable age range and a comparable education level, $90 \%$ were gainfully employed in 2015 . The unemployment rate among this native-born group was $1 \%$ in 2015 while the unemployment rate among this foreign-born group was $6 \%$. Furthermore, $5 \%$ of the native-born group was outside the workforce in 2015 compared to $14 \%$ of the foreign-born group. Similar findings have been reported from the Swiss labour market (Auer et al, 2017). Auger et al (2017) also suggest that longer unemployment can, to some part, be related to discrimination by employers. 
Among the OECD member countries, Sweden has the second-largest difference in employment rates between its foreign-born population and its native-born population. In a report on comparative labour market policies for new arrivals in five OECD countries, Joyce (2017) lists various reasons for this difference. First, Sweden generally has a higher rate of unemployment, especially among women. Second, in Sweden, with its larger share of humanitarian migrants than most other OECD countries, the unemployment rate among these migrants is higher than in all European countries. Third, Swedish labour laws and policies create barriers to workforce integration. For example, even low-skilled workers receive high entry wages, high welfare benefits, and powerful employment protection.

When commenting on immigrant workforce integration, it is important to emphasize that immigrants in Sweden, as elsewhere, are not a homogeneous group. Their work experience, their training, their education, and their family situation vary person to person. It is a complex process to match a new arrival to suitable employment.

One issue in immigrant workforce integration relates to the phenomenon of depopulation, which is increasingly a challenging and expensive problem in many Western countries, including Sweden. Even with government programmes and incentives aimed at economic support of rural regions, more and more young people are moving from the countryside to urban areas. Many immigrants also prefer to live in towns and cities. It is striking that Sweden (and other high-income EU countries) has this depopulation problem given the massive expansion in world population in the last century (Lowder et al., 2016). The problem is worsened by the changing nature of Swedish agriculture. As the number of small and mediumsize family farms has decreased in Sweden, the number of large (often corporation-owned) farms has increased (Barth et al., 2017). Yet, despite some macro-economic studies (e.g., Wiesbrock, 2011), there is little research on immigrant workforce integration, especially in rural areas.

The demographics in Swedish agriculture are also changing. For example, the average age of $30 \%$ of Swedish farmers in the region of Halland (on Sweden's southwest coast), where this research was conducted, is more than 65 years. This is not an unusual statistic in Sweden. In the year 2015, 72\% of Swedish farmers were older than 50 years (Jordbruksverket, 2015). These older farmers, with their shorter work time horizons, are often reluctant to invest in farming equipment innovations and new processes (Läpple et al., 2015). They have also been described as somewhat risk averse, at least when compared with younger farmers (El-Osta and Morehart, 1999). In a study of farmers in Ireland, for example, Läpple et al. (2015) found that younger farmers who manage larger, more intensively-farmed holdings are more likely to engage in agricultural innovation. However, while family farms managed by older farmers continue to play an important role in Swedish agriculture, more farms are operated by younger farmers who rely on hired labour for their operations and who are willing to make farming innovations (Anderson and Lundqvist, 2016).

Another national and international challenge today is the increase in cultural diversity in many countries that were once more or less mono-cultural societies. With the increase in immigration, Sweden and other EU countries have become multicultural societies. This challenge is analysed in this paper that examines "matchmaking" between immigrants and agri-entrepreneurs (hereafter, farmers) in the agricultural sector in Sweden. The paper focuses on growth-oriented agricultural farms as their owners map their growth possibilities and recruitment ambitions in the effort to create sustainable business models.

The aim of this paper is to describe immigrant workforce integration in the agricultural sector as farmers confront the challenges and barriers that an increasingly diversified society presents. The paper addresses these challenges as they were studied in a farm employer-immigrant labourer matchmaking project in the region of Halland, Sweden.

The paper is structured as follows. In the next section the focus is on sustainable business models based on cultural diversity for competitive advantage. The following section describes the paper's research method, including descriptions of the project design and the data collection. Thereafter the paper describes the research findings related to the possibilities for developing a sustainable business model based on a diversified workforce. The paper concludes with discussion of these findings and suggestions for future research. 


\section{SUSTAINALBE BUSINESS MODELS - DIVERSITY FOR COMPETIIVE ADVANTAGE}

Previous research on the agri-food sector has shown the importance of building sustainable business models (e.g., Barth et al., 2017). The research has also revealed how essential it is for agricultural entrepreneurs to act in environmentally and socially responsible ways by taking care of the land and by following conservation-oriented practices (Ulvenblad et al., 2016).

The interest in business models has developed rapidly in the last 15 years with various models proposed that consist of different business elements and building blocks (Chesbrough, 2007; Magretta, 2002; Tell et al., 2016; Teece, 2010; Zott et al., 2011). One well-known model is the Business Model Canvas that Osterwalder et al. (2005) and Osterwalder and Pigneur (2010) developed. This model has nine building blocks: i) customer segments; ii) the value proposition; iii) value channels; iv) customer relationships; v) revenue streams; vi) resources; vii) activities; viii) partnership; and ix) cost structure.

However, such business models, which mainly address for-profit business issues, seldom touch on environmental and social issues. However, as society takes a greater interest in such issues, business model researchers and developers have argued that business owners and managers should consider these issues as they work to achieve sustainable and socially responsible for-profit as well as not for-profit operations. For example, Grassl (2012) describes the motivations behind business models for social ventures. Such models should i) be driven by a social mission in which the primary focus is not shareholder wealth, ii) have a positive impact on society, iii) recognize the centrality of the entrepreneurial function, and iv) support achieving competitiveness in markets through effective planning and management.

According to Alter (2006), the social enterprise model means using revenue activities and financial leverage via business-oriented resource management that enables practitioners to make new social, project-related investments. She proposes further that such resource management is effective when the social investments and business activities can be integrated by commercializing social services in new, fee-paying markets or by providing new services to existing clients. She describes these markets and services as "integrated" social ventures in which the target groups benefit from the investments, irrespective of their involvement in the venture's operations. Value creation in this context involves the social inclusion of less privileged groups. According to Omidvar and Richmond (2003), the overall aim of social inclusion is the closure of the physical, social, and economic distances that separate people rather than the removal of the barriers that separate people.

Diversity management, as envisioned in the sustainable business model for competitive advantage, refers to an organization's capability for embracing cultural diversity and realizing its benefits. This means that successful diversity management, in the company setting, is the ability to be profitable supported by an organizational culture that recognizes/accepts certain diverse values and tolerates/supports diverse cultural backgrounds (Mor Barak, 2000). As diversity management is increasingly associated with issues related to unemployment, poverty, crime, and the environment, it has become more important for social entrepreneurs to consider the role of diversity management at their companies (Cho et al., 2017).

Ely and Thomas (2001) list three reasons why organizations should support cultural diversity at work: i) an organization may adopt cultural diversity as a moral obligation to correct historic discrimination; ii) an organization may embrace cultural diversity to gain access to the markets of a cultural or national group; and iii) an organization may promote cultural diversity as a resource for learning.

A sustainable business model that balances financial, environmental, and social factors for business development will likely embrace cultural diversity. Bocken et al. (2014), in their literature and practice review, present several sustainable business model archetypes. They describe archetypes that aim to accomplish the following: i) Maximise material and energy efficiency, ii) Create value from waste, iii) Substitute with renewables and natural processes, iv) Deliver functionality rather than ownership, v) Adopt a stewardship role, vi) Encourage sufficiency, vii) Re-purpose the business for society/environment, and viii) Develop scale-up solutions. 
In summary, the social entrepreneur must balance financial goals with social and environmental goals in the development of a sustainable business model. In today's world, with its mass migration of large groups of people from country to country, cultural diversity is a reality that the sustainable business model must address. Cultural diversity in the workplace means recognizing and appreciating a diverse workforce.

\section{METHOD}

Two main actors were involved in the integration project, namely the Rural Economy and Agricultural Societies in Halland, and Sweden's public employment Service.

The Rural Economy and Agricultural Societies is a national organization for knowledge transfer in Sweden that dates from the year 1791. Today the organization, which provides advice and education mainly to farmers, consists of 17 independent Rural Economy and Agricultural Societies. Farmers interested in recruiting and integration were identified by the The Rural Economy and Agricultural Societies in Halland.

Sweden's Public Employment Service, which provides employment services to both job seekers and employers, prioritises job seekers who are most removed from the labour market. The Service has 280 local employment offices, organised into 10 market areas across Sweden. Immigrants with experience and interest in agricultural work were profiled by two public employment offices in Halland.

The year-long project ended in December of 2017. Initial interviews were conducted with 80 farmers, clients of The Rural Economy and Agricultural Societies in Halland. The interviews were conducted in winter and early spring in December of 2016 to April of 2017. These times were most convenient for the farmers.

In these initial interviews with the 80 farmers, our aim was to acquire a general understanding of the farmers' business goals and challenges. We also asked the farmers questions related to the work skills needed and their interest in employee recruitment, in particular among the immigrant population. We then arranged a lunch meeting attended by farmers who were interested in the project and by representatives from the local employment offices. The purpose of this meeting was to explain the possibilities for matching the farmer-employers' sought-after employee profiles with the immigrant-labourers' profiles.

We next arranged four meetings attended by the farmers and representatives from the project partners. Sixteen of the 42 farmers were able to attend these meetings that addressed the matchmaking between competence profiles. Representatives from the local employment offices described various employment positions at the meetings. Following these descriptions, we presented results from the farmers' interviews. Then representatives from the employment offices had a 30-minute discussion with each farmer in which the goal was to match a job seeker (an immigrant) to a farmer profile for a soughtafter employee. If the matchmaking succeeded (i.e., a job seeker was found who fit the farmer profile), then a face-to-face meeting was arranged between the farmer and the job seeker. All meetings were documented and evaluated.

We conducted the initial 80 interviews assuming that at least 20 farmers would be interested in employee recruitment and would participate in the matchmaking process. The farmers each employed between 1 and 15 labourers in dairy, pig, cattle, poultry, and crop production and in forestry. After 50 farmers were interviewed, it was clear that no new information was forthcoming. However, we continued with the interviews because the farmers described their interests and challenges somewhat differently.

Although little guidance exists on optimal sample sizes in qualitative research, Mason's (2010) literature review recommends at least 15 interviews and up to 60 interviews in some disciplines. It is unclear why some researchers argue that certain methodological approaches require more participants than others. However, we conclude that the 42 farmers who participated in the matchmaking profile project achieved the level of saturation found in other qualitative studies based on a similar methodological approach.

We used an interview guide in the initial interviews in which we asked questions about the farmers' backgrounds, future plans, and recruitment sought-after features such as employee competences, abilities, 
and characteristics. The interviews, which were semi-structured, had open-ended questions intended to encourage the farmers to talk about their organizations, their experiences with entrepreneurship, and their plans for growth and employee recruitment. The interview responses were documented during the interviews and then analyzed and categorized according to challenges, interests, and employee requirements.

In December of 2017, we conducted the second round of interviews with the 42 farmers who had agreed to continue in the matchmaking profile project. The purpose of these interviews was to follow-up on their recruitment activities.

\section{FINDINGS AND DISCUSSION}

The interviews revealed the farmers' views on business challenges and sought-after employee skills, characteristics, abilities, and tasks. Figure 1 illustrates the findings from these interviews.

\section{FIGURE 1}

\section{FARMERS' PERCEPTION ON RECRUITMENT}

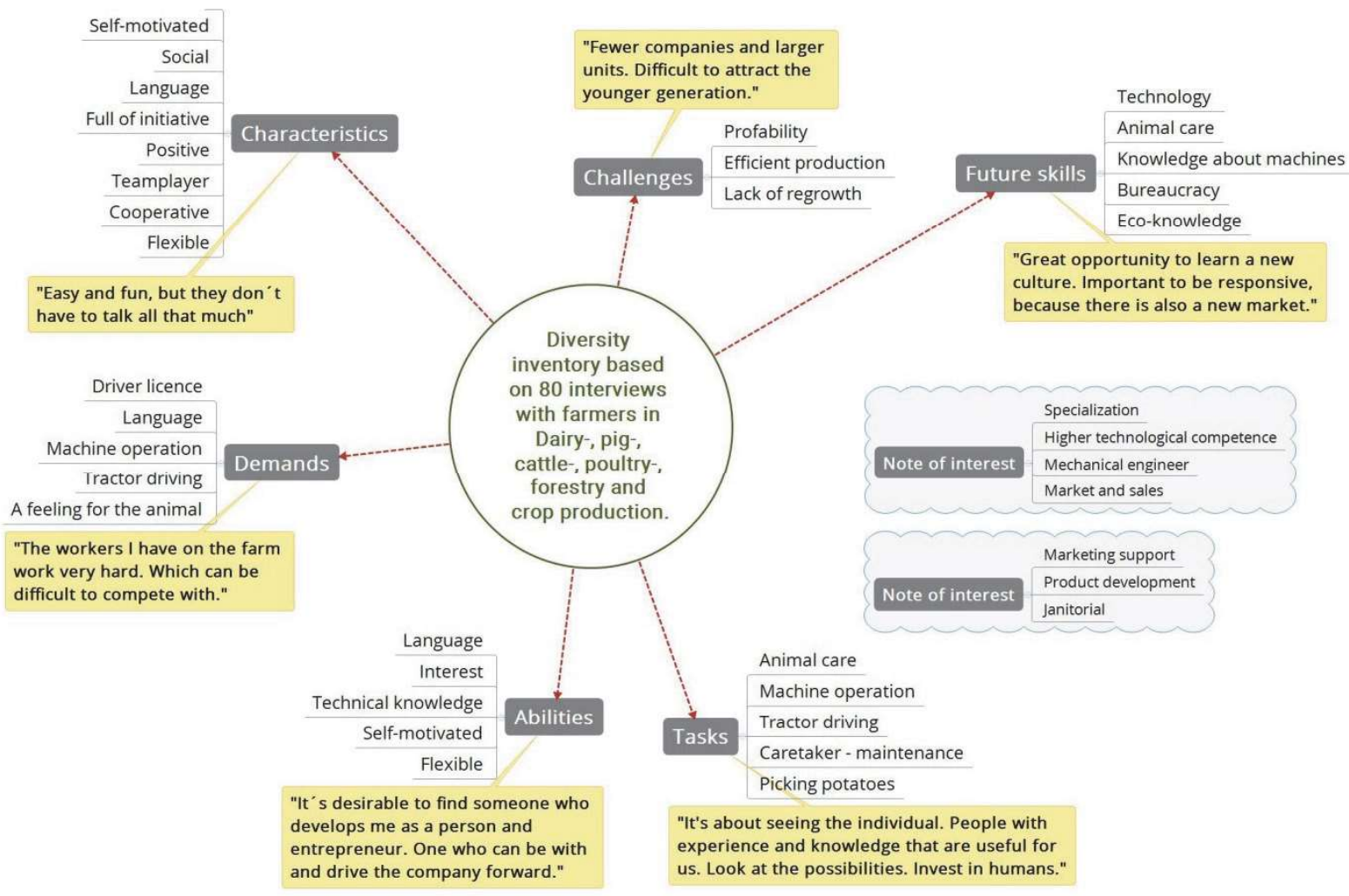

The most required employee competence the farmers identified is technical knowledge. Agriculture is no exception to the increasing digitalization of society in all its aspects. Farming today is a technologically intense activity, and many of the farmers recognize the new possibilities that digitalization provides. Some farmers are now addressing how digitalization challenges their business models e.g., how digitalization affect their business values and their value chain.

Furthermore, the farmers also stress the challenges of attracting the younger generation in the family business. The number of farms are decreasing and are becoming bigger due to increased global competition. These challenges make the farmers view other possibilities and work more proactive as they search for employees outside the family. Anderson and Lundqvist (2016), in their article on "gendered 
time in Swedish family farming," comment on this situation in which hired labourers are replacing family labourers.

The typical farm task included animal care, machine operation, tractor driving, and machinery maintenance. However, tasks identified vary between the farms. Farms with animals stress the need for animal care, while other farmers stress engineering skills such as equipment use and machinery competence. For example, the dairy farmer's particularly emphasized animal care and tractor driving was mentioned in relation to crop production. The administrative work is also growing why administrative tasks also is addressed. Some of the more proactive farms stress the need for new competencies, e.g. new to the farm, which include eco-farming as well as marketing and sales knowledge. Also of interest to note is that some farmers address the individual rather than task:

It's about seeing the individual. People with experience and knowledge who are useful for us. Look at the possibilities, and invest in humans. [Farmer]

Many farmers stated that language is another critical element in their description of the abilities, skills, and characteristics required of farm labourers. Other critical requirements are the ability to drive a tractor and the possession of a driver's license. The farmers also value self-motivation and independence in their hired employees. They are more interested in co-worker relationships than in boss-employee relationships.

The attendance at the four meetings with the representatives from the local employment offices was disappointing. Only 16 of the 42 farmers attended these meetings although most had expressed an interest in them. Contrary to our expectations, the attendees were more interested in social contact than in business issues. Although they expressed an interest in working with new arrivals, yet, by project end, only one farmer had hired immigrants. This farmer had employed three immigrants.

In our analysis of the progression of the project -- from the interviews with the 80 farmers to one farmer's employment of three immigrants -- we concluded that in some cases the farmers simply lacked the time to engage in recruitment and employment activities with immigrants. Farm work is a neverending chore. The farmers who did not hire immigrants were also more accustomed to employing family members. They hesitated to adopt new hiring practices.

We also found that these farmers lacked the resources to deal with the particular needs and cultural differences that such immigrant hiring practices require. Many family farms do not have the HR resources and skills to employ in the management of personnel matters. Developing the informal family business to a formal organisation with employees requires change in skills and leadership. It could be argued that managerial barriers to growth should also be considered when addressing diversity as a competitive advantage.

Our research also supports Barth et al.'s (2017) conclusions regarding the importance of social and environmental responsibility among the farmers. While the farmers in this project mainly failed to employ immigrant labourers, they stated their support of cultural diversity and their commitment to sustainable development. As Conway Dato-on and Kalakay (2016), describe, social entrepreneurship is "a winding road" with multiple pathways (i.e., "dimensions").

\section{CONCLUSIONS}

The paper investigates the growth possibilities for small family farms in the region of Halland (on Sweden's southwest coast). University researchers, government officials, and industry representatives formed a team that planned and conducted a year-long project aimed at assisting a number of farmers with developing a new and more sustainable business model. The specific aim of the project was to match immigrants who were seeking work with the farmers who were seeking labourers. An underlying theme and motivation behind this project was the societal and political necessity in Sweden for greater cultural diversity in the workforce given the country's increasing number of immigrants and asylum refugees. 
Of the 80 farmers contacted, 42 agreed to participate in the matchmaking profile project. They were interviewed on their business challenges and interests, with emphasis on creating profiles of sought-after employees. Of the 42 farmers, 16 participated in meetings in which they were matched with job seekers (immigrants in Sweden). Eventually, one farmer employed three immigrant labourers.

We found that nearly half of the farmers in the original group of 80 farmers declined to participate in the matchmaking profile project. They said they lacked the time for the project and also the resources to "take care" of immigrant labourers. Those who did participate seemed more interested in the socializing aspects of the project than in its business aspects. In addition, most farmers have very specific requirements of new hires. For example, employees must have a driver's license, be able to drive a tractor, and have some mechanical and digital skills. It is often difficult to find immigrant workers who have these qualifications. These barriers may explain why only one farmer followed through on the matchmaking process.

Additional research is needed that addresses the employment challenges and barriers in the agricultural sector when governments' social and political aims are to help new arrivals find gainful employment and to manage rural depopulation. The increase in mass migration to Europe, which may be expected to continue for some years, means people from different cultures have to live and work together.

A sustainable business model in the agricultural sector, therefore, aims at cultural diversity as well as financial viability. Researchers can investigate how a successful balance between these two workplace aims, not necessarily conflicting, can be achieved.

\section{ACKNOWLEDGEMENT}

This project was supported by the Swedish Agency for Economic and Regional Growth, and Region Halland. Special thanks to Håkan Eriksson, Rural Economy and Agricultural Societies in Halland, for the assistants of data collection and mapping the illustrative challenges for the farmers. Also thanks to Lisa Olsson, Public Employment Service in Halmstad, for providing input to the matching process with immigrants.

\section{REFERENCES}

Alter, S. K. (2006). Social Enterprise Models and Their Mission and Money Relationships. In A. Nicholls (Ed.), Social Entrepreneurship: New Models of Sustainable Social Change. Oxford: Oxford University Press, pp. 205-232.

Andersson, E., \& Lundqvist, P. (2016). Gendered Time in Swedish Family Farming: Operationalizing an Agrarian Typology Using the Swedish Farm Accountancy Data Network. Journal of Family Business Management, 6(3), 310-329.

Asylum and first time asylum applicants by citizenship, age and sex Annual aggregated data (rounded). (2018, October 24). Eurostat. Retrieved from http://appsso.eurostat.ec.europa.eu/nui/show.do?dataset=migr_asyappctza\&lang=en

Auer, D., Bonoli, G. and Fossati, F. (2017). Why do immigrants have longer periods of unemployment? Swiss evidence. International Migration, 55(1), 157-173.

Barth, H., Ulvenblad, P.-O., \& Ulvenblad, P. (2017). Towards a Conceptual Framework of Sustainable Business Model Innovation in the Agri-Food Sector: A Systematic Literature Review. Sustainability, 9, 1620.

Bocken, N. M. P., Short, S. W., Rana, P., \& Evans, S. (2014). A Literature and Practice Review to Develop Sustainable Business Model Archetypes. Journal of Cleaner Production, 65, 42-56.

Chesbrough, H. (2007). Business Model Innovation: It's Not Just About Technology Anymore. Strategy \& Leadership, 35(6), 12-17. 
Cho, S., Ahraemi, K., \& Mor Barak, M. E. (2017). Does Diversity Matter? Exploring Workforce Diversity, Diversity Management, and Organizational Performance in Social Enterprises. Asian Social Work Policy Review, 11, 193-204.

Conway Dato-on, M., \& Kalakay, J. (2016). The Winding Road of Social Entrepreneurship Definitions: A Systematic Literature Review. Social Enterprise Journal, 12(2), 131-150. https://doi.org/10.1108/SEJ-06-2015-0016

Ely, R. J., \& Thomas, D. A. (2001). Cultural Diversity at Work: The Effects of Diversity Perspectives on Work Group Processes and Outcomes. Administrative Science Quarterly, 46(2), 229-273.

El-Osta, H. S., \& Morehart, M. J. (1999). Technological Adoption Decisions in Dairy Production and the Herd Expansion. Agricultural and Resource Economic Review, 28, 84-95.

Grassl, W. (2012). Business Models of Social Enterprise: A Design Approach to Hybridity. ACRN Journal of Entrepreneurship Perspectives, 1(1), 37-60.

Jordbruksverket. (2015). The Yearbook of Agricultural Statistics. Retrieved 2017-05-27 from http://www.jordbruksverket.se/download/18.4d857f2814e3cf3eeda2b510/1435577114308/Summ ary+2015.pdf. Viewed 21 December 2017.

Joyce, P. (2017). Inspiration for Integration. ESO-raport om arbetsmarknadspolitik för nyanlända i fem lander [Inspiration for Integration, ESO Report on Labour Market Policy for New Arrivals in Five Countries] Expertgruppen för studier i offentlig ekonomi 2017:7, Stockholm.

Lowder, S. K., Skoet, J., \& Raney, T. (2016). The Number, Size, and Distribution of Farms, Smallholder Farms, and Family Farms Worldwide. World Development, 87, 16-29.

Läpple, D., Renwick, A., \& Thorne, F. (2015). Measuring and Understanding the Drivers of Agricultural Innovation: Evidence from Ireland. Food Policy, 51, 1-8.

Magretta, J. (2002). Why Business Models Matter. Harvard Business Review, 80, 3-8.

Mason, M. (2010). Sample Size and Saturation in PhD Studies Using Qualitative Interviews. Forum: Qualitative Social Research, 11(3) [Article No. 8].

Mor Barak, M. E. (2000). Beyond Affirmative Action: Toward a Model of Diversity and Organizational Inclusion. Administration in Social Work, 23(3-4), 47-68.

Omidvar, R., \& Richmond, T. (2003). Immigrant Settlement and Social Inclusion in Canada, Toronto: Laidlaw Foundation.

Osterwalder, A., \& Pigneur, Y. (2010). Business Model Generation: A Handbook for Visionaries, Game Changers, and Challengers. Hoboken, NJ: John Wiley \& Sons.

Osterwalder, A., Pigneur, Y., \& Tucci, C. L. (2005). Clarifying Business Model: Origins, Present, and Future of the Concept. Communications of the Association for Information Systems, 16 [Article No. 1].

Statistics Sweden. (2017). Matching Between Education and Occupation Among Foreign-born in Sweden. Integration Report 11, Statistics Sweden.

Teece, D. J. (2010). Business Models, Business Strategy and Innovation. Long Range Planning, 43(2-3), $143-462$.

Tell, J., Hoveskog, M., Ulvenblad, P., Ulvenblad, P.- O., Barth, H., \& Ståhl, J. (2016). Business Model Innovation in the Agri-food Sector: A Literature Review. British Food Journal, 118(6), $1462-$ 1476.

Ulvenblad, P-O., Ulvenblad, P. \& Tell, J. (2016). Green Innovation in the Food Value Chain - Will Goliath Fix It - or Do We Need David? Extended Abstract presented at the $61^{\text {st }}$ International Council for Small Business (ICSB) World Conference, $15^{\text {th }}-18^{\text {th }}$ June, New York, USA.

Wiesbrock, A. (2011). The Integration of Immigrants in Sweden: A Model for the European Union? International Migration, 49: 48-66. doi:10.1111/j.1468-2435.2010.00662.x

Zott, C., Amit, R., \& Massa, L. (2011) The Business Model: Recent Developments and Future Research. Journal of Management, 37(4), 1019-1042. 